\title{
SCIENTIFIC CENTENARIES IN 1952
}

\author{
By Eng.-Captain EDGAR C. SMITH, O.B.E., R.N.
}

IT is probable that no centenary commemorations 1 in 1952 will excite wider interest than those being arranged in connexion with the five-hundredth anniversary of the birth of Leonardo da Vinci, painter, sculptor, architect, engineer and inventor, and recognized as one of the greatest of them all. Born on April 15, 1452 (O.S.), at Vinci, between Pisa and Florence, he was the natural son of Piero da Vinci, a Florentine notary, and Catherine, a peasant girl. Both his parents married in their respective stations; but Leonardo was treated by his father as his legitimate son. His remarkable talents being recognized, he was apprenticed to the Florentine goldsmith and painter Andrea del Verrochio (143588). When about twenty-eight he visited the East and on returning to Italy in 1482 settled at Milan, where he was patronised by Ludovica Sforza, the Duke; but after the fall of his patron in 1500 , Leonardo entered the service of Cesare Borgia, then Duke of Romagna, as artist, architect and engineer. His fortunes were, however, much affected by the incursion of the French into northern Italy, and in 1508 he was employed by Louis XII. Eight years later, Francis I of France gave him the Châtęu of Cloux, near Amboise, as his place of residence, and there he died on May 2, 1519, and was buried. $\mathrm{H}_{\Theta}$ was then sixty-seven and unmarried. "No character in history," said one writer, "corresponds more closely to our idea of the man of genius than Leonardo da Vinci."

Born a few years after the invention of printing and a year before the capture of Constantinople by the Turks, Leonardo counted among his older contemporaries Cabot, Columbus and Regiomontanus, and among his younger contemporaries Michelangelo, Raphael, Copernicus, Erasmus and Luther. $\mathrm{He}$ was essentially a forerunner, and it was a misfortune for the world that his manuscripts, full as they are of observations, calculations, ingenious devices and speculations, should have been scattered and lost sight of for two and a half centuries. Since their discovery, however, a vast literature relating to Leonardo has sprung up, from which it is seen that his work has as much interest for the man of science as the artist. In a lecture at the Royal Institution, published in Nature of May 6 and 13, 1920, Mr. Edward McCurdy said that "Leonardo's researches in natural and applied science cover so wide a field, and specialization in these days has so divided knowledge into water-tight compartments, that properly to gauge the value of his contributions to scientific research would require a combination of many trained intelligences".

Leonardo counted among his intimate friends the mathematician Luca Pacioli, the author of the earliest printed work on arithmetic and algebra, and it was their collaboration which led to the establish. ment of an academy of arts in which the study of geometry was cultivated. Other academies sprang up in Italy in the sixteenth century, but it was not until the first half of the following century that the gatherings of scientifically inclined men took place in England which led to the foundation of the Royal Society in 1660. The gatherings in London were closely connected with the activities of the professors of Gresham College, housed from 1596 in the old mansion in the City of the Elizabethan magnate Sir Thomas Gresham. There were seven chairs in all, including those of geometry and astronomy, the holders of which included Peter Turner, Dr. John Greaves and Samuel Foster, who all died in 1652. Turner, the son of a physician who attended Raleigh in the Tower of London, and Greaves, the son of $a$ Hampshire rector, were both Fellows of Merton College, Oxford ; and, while Turner in 1620 and 1630 respectively succeeded Briggs as Gresham professor of geometry and Savilian professor of geometry, Greaves was Turner's successor in London in 1630 and the successor of Dr. John Bainbridge as Savilian professor of astronomy in 1643. Both were royalists, and in 1648 this led to their being deprived of their chairs, after which they retired to London, where both died and were buried. Their contemporary, Samuel Foster, a native of Northamptonshire, was educated at Emmanuel College, Cambridge, his connexion with which probably led to his friendship with Jeremiah Horrocks. Removing to London, he held the Gresham chair of astronomy for a few months in 1636, and again from 1641 until his death in the College in May 1652. He was one of the first promoters of experimental science in England, and joined with Wallis, Wilkins and others in the meetings, at which "Our business was," as wrote Wallis, "... to discourse and consider of Philosophical Enquiries, and such as related thereunto : as Physick, Anatomy, Geometry, Astronomy, Navigation, Staticks, Magneticks, Chymicks, Mechanicks and natural Experiments".

Other scientific tercentenaries which occur this year are those of the births of the French mathematicians, Michel Rolle (1652-1719) and Paul l'Hoste (1652-1700), and the German chemist, Wilhelm Homberg (1652-1715). Rolle was long a teacher in Paris, where he was given a pension by Colbert, and a seat in the Royal Academy of Sciences, while l'Hoste, a Jesuit, held a chair of mathematics at the Naval School at 'Toulon and published a work on naval construction. Homberg's birthplace was Batavia, Java, where his father was a commandant. The family returning home, young Homberg studied law at Leipzig and became an advocate at Magdeburg. But science proved a stronger attraction, and after travelling and studying here and there, in 1691 he settled in Paris, became physician to the Duke of Orleans, married the daughter of the botanist Dodart, and was made director of the laboratory at the Academy of Sciences; he was regarded as one of the most learned chemists of his age.

Passing from the tercentenaries to the bicentenaries, no apology is needed for including that interesting character, Dr. William Whiston, who was born on December 9, 1667, and died at the age of eighty-four on August 22, 1752. The son of a Leicestershire parson, and himself at one time vicar 
of Lowestoft, his mathematical attainments led Newton to choose him for his deputy and successor as Lucasian prufessor of mathematics, to which post he was appointed in 1703. But like Newton, Boyle, Priestley and others, Whiston studied and wrote on theology, and his unorthodox views led to his being deprived of his chair in 1710, and from that time he lived mainly by lecturing and writing. His death took place at Lyndon, Rutland, where his tomb can be seen. Known to three generations of men of science, the friend of Cotes, Hauksbee, Halley, Flamsteed and Woodward, as well as to men such as Addison and Steele, Whiston in his memoirs describes how his lectures and writings on the solar eclipse of 1715 brought him presents from noblemen-"twenty guineas from the Duke of Newcastle"--by which he gained altogether £120, "which in the circumstances I then was, and have been since, destitute of all preferment was a very seasonable and plentiful supply, and as I reckoned maintained me and my family for a whole year afterwards". Given much to keeping fasts, on one occasion when he refused a glass of wine, Halley told him, "He was afraid I had a pope in my belly".

The tale of 1752 includes the names of men famous in their own time, and of men famous for all time. In the month of February 1752 was born the Italian natural philosopher, Giovanni Fabroni (d. 1822), contemporary of Galvani and Volta, a writer on the voltaic pile and, under Napoleon, a holder of public offices. The month of June saw the birth of the French astronomer, Joseph Beauchamp, who accompanied the ill-fated expedition of Napoleon to Egypt and who died in 1801 soon after his release from captivity by the British. July not only saw the birth of another Italian man of science, Barnaba Oriani (d. 1832), at one time director of the Brera Observatory at Milan, and of the Swiss natural philosopher, Marc Auguste Pictet (d. 1825), who succeeded to the chair held by de Saussure at Geneva, but also the birth of Joseph-Marie Jacquard (d. 1834), one of France's greatest mechanical inventors, who combined the devices of others with his own to give the world the 'Jacquard' loom for the weaving of figured goods. The events of the French Revolution and the reign of Napoleon both affected the fortunes of Jacquard ; but his latter days were passed pleasantly enough. His birthplace was Lyons, and it was the Lyons municipality which set up his statue. Lastly, the month of September 1752 saw the birth at T'oulouse of the eminent French mathematician Adrien-Marie Legendre, whose name is frequently associated with those of Lagrange and Lapluce. Legendre seems to have been singularly unaffected by the momentous events of his time, and he continued to labour almost to the day of his death, which occurred on January 10, 1833, at Auteuil.

Turning from the story of 1752 to that of 1852 , an interesting but little-known figure is that of the Finnish chemist, Johann Gadolin, who died on August 15, 1852, at the age of ninety-two, and whose biography was reviewed in $\Lambda$ ature of March $9,1911$. A member of a family long associated with scholarship in Finland, he was born in Abo, of which his father became the bishop. A student under Berg. mann and a friend of Scheele, in 1785 he became an extraordinary professor at Abo and in 1797 succeeded to the chair left vacant by the death of Peter Adrian Gadd, Finland's first professor of chemistry. Gadolin travelled in Germany, Holland, England and
Ireland, and supported the views of Lavoisier. In 1795 he discovered the rare earth yttria, from which yttrium was obtained by Wöhler. Gadolin continued to hold his chair until 1822, by which time the port and town had passed from the control of Sweden to that of Russia. Visited in 1805 by Reginald Heber, the future bishop of India, Abo was described by him as "a place possessing an archbishop, fifteen professors, three hundred students, a ruined castle, a whitewashed cathedral and certainly the most northerly university in Europe". In 1827 the place was almost entirely destroyed by fire.

Just as Gadolin promoted the study of the new chemistry in Finland, so did his somewhat younger Scottish contemporary, Dr. Thomas Thomson (17731852), by his writings further the study of the atomic theory of Dalton, whom he visited at Manchester in 1804. Born at Crieff, Perthshire, Thomson attended the lectures of Black in the University of Edinburgh, and having in 1799 graduated M.D., took to writing and lecturing on chemistry and allied subjects. In 1813 he founded the Annals of Philosophy, which later on was merged in The Philosophical Mayazine, and in 1818 he became the first regius professor of chemistry in the University of Glasgow. The laboratory he founded was one of the first, if not the first, for chemical research and the practical instruction of university students in chemistry, and this "at a time", said Lord Kelvin, "when an imperfectly informed public used to regard the University of Glasgow as a stagnant survival of medievalism and to call its professors the Monks of Molindinar !"

Thomson was a Fellow of the Royal Society, as also were John George Children (1777-1852), George Dollond (1774-1852), Major-General Thomas Colby (1784-1852), Gideon Algernon Mantell (1790-1852) and William Tierney Clark (1783-1852). Children, like his father (George Children (1742-1818), the Kentish banker), was known for his experiments with large galvanic batteries; but afterwards he was active as a librarian at the British Museum. He translated the works of Thenard and Berzelius, and was a secretary of the Royal Society and a founder and the first president of the Entomological Society. Dollond was for many years head of the well-known firm of opticians and instrument makers, while Colby spent nearly all his life on the Ordnance Survey of Great Britain and Ireland, of which he became superintendent in 1820. Mantell was in the front rank of geologists, and Clark was a leading civil engineer. His masterpiece was the wrought-iron chain suspension bridge over the Danube at Budapest. First used in January 1849 , as a way of retreat for the Hungarians, in 1944 it was destroyed by the retreating Germans, but has since been rebuilt, much of Clark's original chains being used.

In the roll of notable physical scientists born a century ago, many countries are represented, and it includes no fewer than six Nobel prizemen-Fischer, Michelson, Moissan, Henri Becquerel, Van't Hoff and Sir William Ramsay. Emil Fischer (1852-1919) was born in Rhenish Prussia and studied at Bonn and Strassburg. After holding other positions, in 1892 he succeeded Hofmann in the chair of chemistry at Berlin, and in the following year was made a foreign member of the Chemical Society of London. In a notice of him in Nature of July 31, 1919, Prof. H. E. Armstrong said that when he first met Fischer in Strassburg in January 1882, "he all but fell in love with him on the spot", and that "no chemist has secured success to a greater extent through con- 
stantly enforced intellectual effort and the determination, having once conceived an object, to win through". Albert Abraham Michelson (1852-1931), both Copley medallist and Nobel prizeman, was also born in Germany, at Strelno, Prussia; but was taken in infancy to San Francisco, and except for periods of study in Europe, was connected all his life with American institutions and universities. His work on optics and the velocity of light made him famous all the world over, and he was regarded as " $a$ prince of experimentalists". Henri Moissan (1852-1907) and Antoine-Henry Becquerel (1852-1908) represent the great French men of science in the list of centenaries, the former being remembered for his isolation of fluorine, his experiments in the manufacture of artificial diamonds and his development of the electric furnace, while Becquerel's paper of February 24, 1896, entitled "Radiations émisés par Phosphorescence", forms a landmark in the story of radioactivity. The Moissan Memorial Lecture to the Chemical Society was delivered by Sir William Ramsay, and that on Becquerel by Sir Oliver Lodge. To the Paris Academy of Sciences Becquerel bequeathed 100,000 francs in memory of his famous father and grandfather, while Moissan's son, Louis, who was killed in action on August 10, 1914, left a sum of 200,000 francs to the École Supérieure de Pharmacie in memory of his father and mother. A statue of Moissan was unveiled at Meaux in 1931.

Holland's representative in the roll of honour for 1952 is the great physical chemist and pioneer of modern electrochemistry, Jacobus Hendrikus van 't Hoff, who was born at Rotterdam on August 30, 1852, and died at Steglitz, Berlin, on March 1, 1911. A student under Kekulé at Bonn and under Wurtz in Paris up to the age of forty-four, he was principally assuciated with Utrecht and Amsterdam, but in 1896 he became professor of chemistry in the University of Berlin, where he remained for the rest of his life. His famous British contemporary, Sir William Ramsay, was born in Glasgow on Octubor 2, 1852, and died at Haslemere, High Wycombe, Bucks, on July 23, 1916. From the laboratories of Bunsen at Heidelberg and of Fittig at Tübingen, Ramsay returned home to become an assistant at the old Andersonian College, Glasgow. As the first professor of chemistry and then as principal, he founded the reputation of University College, Bristol, from which the present University sprang, and then in 1887 succeeded Williamson at University College, London. An acknowledged leader, the recipient of numerous honours, an international memorial fund in his honour, opened in 1917 , had by 1922 reached a total of $£ 58,000$, contributions being sent to it from places as far afield as Chile, India and Japan; and on November 3, 1922, a bronze medallion tablet to his memory was unveiled in "Science Corner", Westminster Abbey, by the King, then the Duke of York.

The founding of the University of Bristol in 1909 had been preceded by the inauguration of those at Birmingham (1900), Liverpaol (1963), Manchester (1903), Leeds (1904) and Sheffield (1905), all of which have been served by men distinguished in various branches of learning. The University of Birmingham owed the creation and development of its flourishing school of physics to John Henry Poynting, who was born near Manchester on September 9, 1852. A student of Owens College, Manchester, and a Fellow of Trinity College, Cambridge, from 1880 until his death on March 30,1914 , he held the chair of physics in Mason College and the University of Birmingham, and for twelve years was dean of the Faculty of Sciences. A close friend and collaborator with Sir J. J. Thomson, he was well known for his researches on electromagnetism, gravity and the pressure of light. The chair of electrical engineering at Birmingham was founded in 1904, and to it was appointed the Austrian-born engineer, Gisbert John Edward Kapp (1852-1922). Educated at Zurich, he went to England in 1875, and gradually built up an international reputation as an inventor, designer, writer and consultant. From 1894 until 19凶4, he was secretary and editor of the German Association of Electrical Engineers. In 1909 he was president of the Institution of Electrical Engineers, and in 1913 was president of the Engineering Section of the British Association. Owens College and the University of Manchester during this same period had as its professor of chemistry Harold Baily Dixon (1852-1930), who had succeeded Roscoe in 1886 and held the chair until 1922. He was especially known for his work on explosives and explosions, and served on various government commissions. He was twice president of the Manchester Literary and Philosophical Suciety, and president of the Chemiced Society during 1949-11. In 1913 he received a Royal Medal from the Royal Society.

To complete the tale of centenaries of men a word or two must be said of the enthusiastic meteorologist Clement Lindley Wragge (1852-1923), who was a pioneer in making meteorological observations on Ben Nevis, in Scotland, and founded several observatories in Australia, where he was head of the Weather Bureau at brisbane; and of the astronomer John Louis Emil Dreyer (1852-1926), who, like Kapp, wes foreign born. The son of a Danish Minister of War and Marine, he was born and educated in Copenhagen and seems to have had an inborn love of astronomy. At the age of twenty-two he left Denmark for Ireland, where he was successively an assistant at Lord Rosse's Observatory, Birr Castle (1874-78), an assistant at Dunsink Observatory (1878-1882) and director of the Armagh Observatory from 1882 until 1916. His magnum opus was the great work in fourteen volumes containing the astronomical work and correspondence of Tycho Brahe, published by the Carlsberg Foundation of Copenhagen. A Fellow of the Royal Astronomical Snciety from 1875 onwards, he was awarded its Gold Medal in 1916, and in 1923 was elected president. For the last ten years of his life he made Oxford his home; he died there on September 14, 1926, at the age of seventy-four.

Of the centenaries of events which fall in 1952, such as the bicentenary of Franklin's kite experiments and the bicentenary of the adoption of the Gregorian calendar by Great Britain in 1752-when September 3 was reckoned as September 14-an important improvement affecting engineers, inventors and scientists was the passing a hundred years ago of the Patent Law Amendment Act, 1852, which "completely recast the somewhat antiquated system that had been in use during the whole of the previous three centuries". Under this Act, Bennet Woodcroft (18(3-79), F.R.S., was made superintendent of specifications and then clerk to the Commissioners, and to his ability and energy Great Britain owed the publication of all specifications from 1617 to 1852, numbering 14,359, the inauguration of the Patent Office Library and the founding of the Patent Office Museum, the nucleus of the Science Museum. 